\title{
PENENTUAN PERLAPISAN BATUGAMPING FORMASI RAJAMANDALA MENGGUNAKAN METODE GROUND PENETRATING RADAR DI DAERAH PADALARANG, KABUPATEN BANDUNG
}

\section{DETERMINATION OF RAJAMANDALA FORMATION LIMESTONE LAYER BY USING GPR METHOD AT PADALARANG, BANDUNG REGENCY}

\author{
Hans E A Siregar ${ }^{1}$ dan Eki Komara ${ }^{2}$ \\ ${ }^{1}$ Pusat Sumber Daya Mineral Batubara dan Panas Bumi \\ ${ }^{2}$ Program Studi Magister Teknik Geofisika, Fakultas Teknik Pertambangan \\ dan Perminyakan Institut Teknologi Bandung \\ hans.elmauri@gmail.com
}

\begin{abstract}
ABSTRAK
Batugamping Formasi Rajamandala sangat menarik untuk diteliti karena batuannya tersingkap secara luas di permukaan. Batugamping terbentuk di wilayah laut dangkal yang tersingkap menjadi perbukitan karena gejala tektonik berupa subduksi dan lipatan. Penelitian dilakukan dengan menggunakan Ground Penetrating Radar (GPR) untuk mengetahui sebaran fasies batugamping. Penelitian ini meliputi, pengambilan data pada frekuensi 75 $\mathrm{MHz}$, pengolahan data dengan menggunakan perangkat lunak ReflexW, dan interpretasi data lapangan. Data bor digunakan untuk membantu interpretasi sebaran fasies dalam arah vertikal. Frekuensi antena yang digunakan adalah $75 \mathrm{MHz}$. Penggunaan frekuensi ini memberikan kemampuan resolusi yang cukup baik dengan jangkauan kedalaman yang memenuhi target. Proses pengolahan data GPR dilakukan dengan tahapan, penapisan noise, penguatan sinyal gelombang, proses bandpass frekuensi, dekonvolusi, stack trace, migrasi kirchoff, penapisan $f$-k-filter, dan penerapan koreksi statik. Data yang sudah diolah kemudian diinterpretasi dan dianalisis sehingga didapatkan sebaran fasies dan struktur batugamping. Daerah Cikamuning sekitar sumur $\mathrm{X}$ merupakan daerah slope dari terumbu, karena didominasi oleh fasies batugamping packstone-grainstone dan floatstone-rudstone dengan arah pengendapan timurlaut - baratdaya.
\end{abstract}

Kata kunci: fasies batugamping, Formasi Rajamandala, frekuensi alat GPR, pemrosesan data, interpretasi data

\section{ABSTRACT}

Limestone of the Rajamandala Formation is very interesting object to be studied since those outcrops are widely exposed on the surface. Limestone was formed in shallow marine areas and then it was exposed into the limestone ridge because the subduction and the tectonic fold mechanisms. A research to comprehend the distribution of the limestone facies was conducted by using GPR method, which includes as follows: GPR data acquisition with antenna frequency of $75 \mathrm{MHz}$, data processing using ReflexW, and interpretation of the data. Borehole data were used to lead facies distribution interpretation in vertical direction. The GPR antenna frequency used is $75 \mathrm{MHz}$. It gives reliable resolution and can penetrate to the depth target. The data processing was conducted by followingsteps: static correction, noise filtering, wave gaining, bandpass frequency filtering, deconvolution, stack trace, kirchoff migration, $f-k$ filtering and set the static correction. The procesed data were interpreted into distribution of facies and structure of limestone. The Cikamuning area around the well $X$ is interpreted as the slope of the reef because it is dominated by packstonegrainstone facies limestones and floatstone-rudstone with its deposition is trending northeast-southwest. 
Keywords: limestone facies, Rajamandala Formation, GPR frequency, data processing, data interpretation

\section{PENDAHULUAN}

Formasi Rajamandala tersingkap luas di daerah Padalarang-Jawa Barat, mulai dari daerah Cikamuning (Tagogapu) di bagian timur sampai Saguling di bagian barat (Siregar, 2005). Sebaran formasi ini membentuk perbukitan rendah berketinggian antara 400 meter s.d. 900 meter di atas permukaan laut. Batugamping pada formasi ini menjadi bahan tambang untuk berbagai industri yang tersebar di daerah ini, seperti industri teraso, ubin, perabotan rumah dan hotel, tepung kalsit, pupuk dan sebagainya. Aktivitas penambangan telah mengupas sebagian besar singkapan di daerah ini, sehingga memudahkan akses penelitian. Namun di lain pihak, sebagian besar dari batugamping yang tersingkap dan berguna bagi ilmu pengetahuan kebumian telah hilang, sehingga singkapansingkapan kunci untuk petunjuk lingkungan pengendapan sulit ditemukan.

Maksud dan tujuan penelitian ini adalah untuk mengetahui sebaran batuan, stuktur, dan stratigrafi batugamping Formasi Rajamandala dengan menggunakan metode Ground Penetrating Radar (GPR) di sekitar sumur $X$ Cikamuning. Teknologi GPR merupakan metode yang tepat untuk mendeteksi stratigrafi, geostruktur, atau benda-benda dalam tanah yang berada di kedalaman dangkal $(0,1$ meter s.d. 50 meter).

Untuk mendapatkan informasi pada data radargram, perlu dilakukan analisis radar fasies berdasarkan perbedaan refleksi gelombang radar yang parameternya berupa konfigurasi, amplitudo, kontinuitas, frekuensi, kecepatan interval, atenuasi dan dispersi pada tiap kelompok gelombang radar (Baker, 1991).

\section{GEOLOGI DAERAH PENELITIAN}

Formasi Rajamandala tersingkap luas di daerah Padalarang Kabupaten Bandung Barat Provinsi Jawa Barat (Gambar1). Singkapan Formasi Rajamandala mulai dari daerah Cikamuning (Togogapu) di bagian timur sampai Saguling di bagian barat dan tersebar membentuk perbukitan berketinggian antara 400 meter s.d. 900 meter di atas permukaan laut (Nugroho, 2009). Secara fisiografi, Formasi Rajamandala termasuk ke dalam bagian Cekungan Bandung. Cekungan Bandung dimulai dari daerah Nagreg di bagian timur sampai ke Padalarang di sebelah barat dengan jarak horizontal sekitar $60 \mathrm{~km}$ sedangkan jarak utara-selatan sekitar 40 $\mathrm{km}$.

Berdasarkan Siregar (2005), stratigrafi daerah Padalarang (Gambar 2), memiliki satuan tertua berupa Formasi Batuasih, yang disusun terutama oleh batulempung dengan sisipan sedikit batupasir kuarsa dan batupasir konglomeratan. Singkapan formasi ini secara setempat dapat diamati di utara Pasir Batununggul-Tanggulun Manik dan juga di sebelah utara Pasir Masigit-Pawon-Bengkung. Formasi Batuasih terbentuk pada lingkungan yang sangat bervariasi (delta), pelengseranpelengseran batuan berlingkungan dangkal ke tempat yang lebih dalam bisa terjadi. Formasi Rajamandala terletak selaras di atas Formasi Batuasih. Formasi ini terdiri dari dua anggota yaitu anggota batugamping dan anggota batulempung dan napal. Hubungan kedua anggota adalah menjemari. 


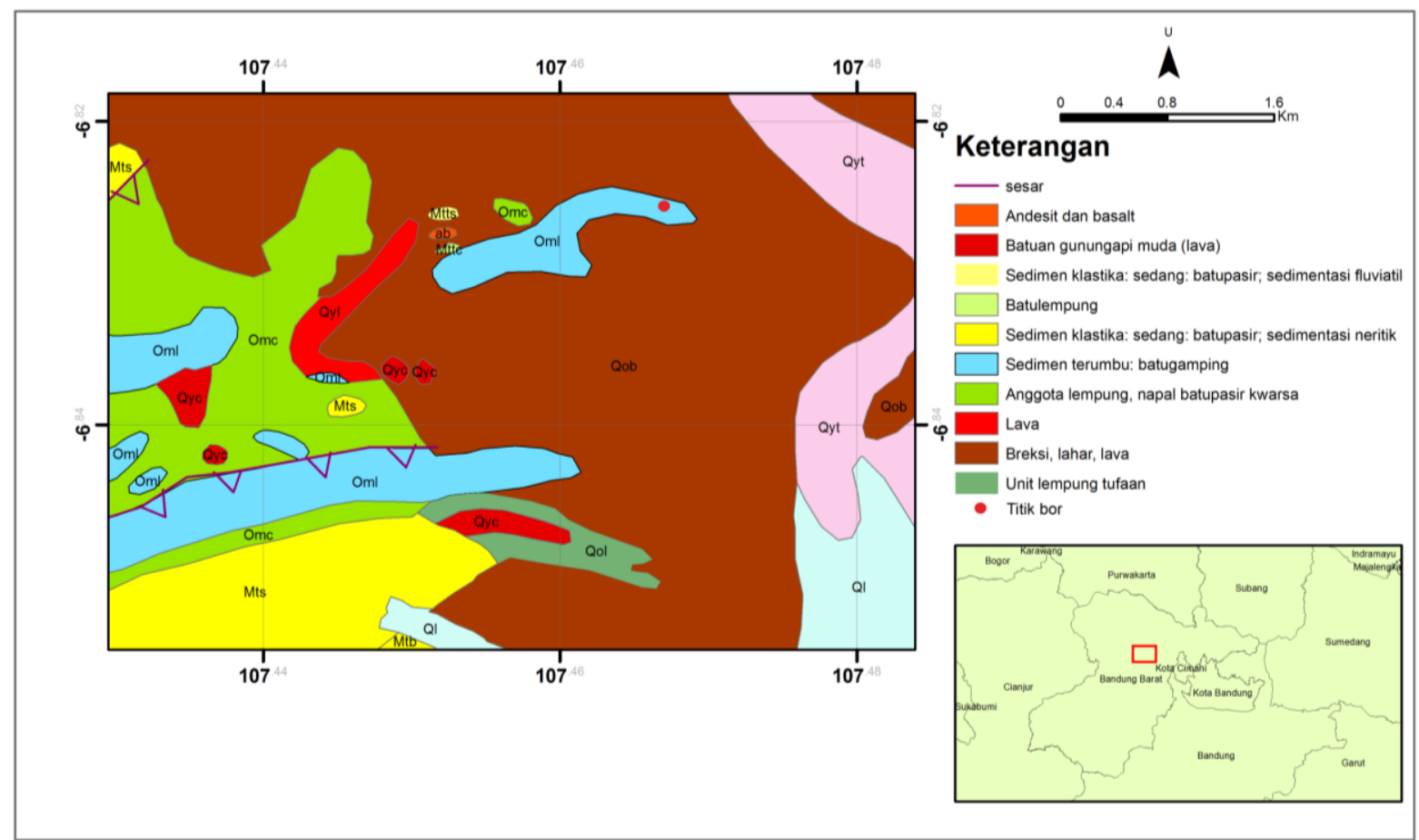

Gambar 1. Peta geologi daerah Rajamandala dan sekitarnya (modifikasi dari Sudjatmiko, 1972)

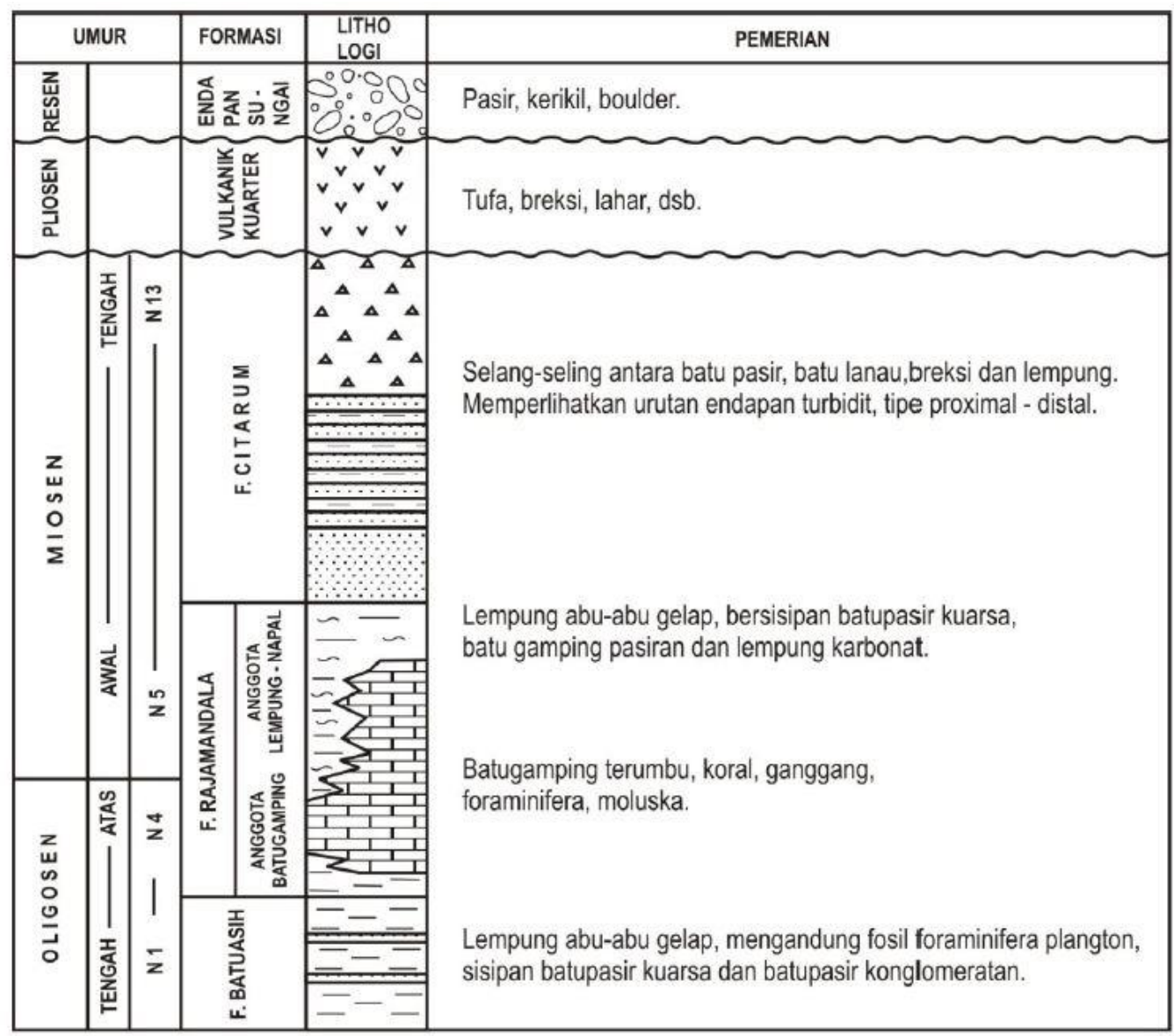

Gambar 2. Susunan stratigrafi daerah Rajamandala (Siregar, 2005) 
Formasi Citarum menutup selaras Formasi Rajamandala. Formasi ini terdiri dari selang seling batupasir greywacke, breksi vulkanik, dan serpih hitam. Pada batupasir banyak ditemukan struktur sedimen gradded bedding, parallel lamination, dan convolute lamination. Formasi Citarum ditafsirkan terbentuk sebagai endapan turbidit yang dipengaruhi oleh aktifitas vulkanik berumur mulai dari bagian atas Miosen Bawah sampai Miosen Tengah.

\section{METODOLOGI}

GPR adalah metode geofisika yang memanfaatkan sifat-sifat kelistrikan dan kemagnetan gelombang elektromagnetik dengan selang frekuensi radio $(1 \mathrm{MHz}$ s.d. $1000 \mathrm{MHz}$ ), dalam menggambarkan profil bawah permukaan. Pada studi kasus ini digunakan frekuensi alat $75 \mathrm{MHz}$ dengan tujuan untuk mendapatkan kedalaman yang ditargetkan dengan resolusi yang cukup bagus.

Dengan resolusi yang tinggi, GPR mampu mendeteksi benda atau struktur geologi ukuran kecil seperti patahan, void, rekahan, dan sebagainya (Annan and Davis, 1989). Adapun tahap penelitian georadar yang dilakukan adalah akusisi data, pemrosesan data, dan interpretasi data.

Alur penelitian pada ini adalah akusisi data, pengolahan data, interpretasi yang dilakukan dengan bantuan data bor untuk mengetahui sebaran litofasies arah vertikal (Gambar 3).

\section{Teknik Akusisi}

Daerah survei GPR pada studi kasus ini terletak sekitar sumur $X$ Cikamuning, Padalarang, Kabupaten Bandung Barat, seperti ditunjukkan oleh lingkaran merah pada Gambar 1. Koordinat sumur penelitian 6048'55" LS dan $107^{\circ} 27^{\prime} 54^{\prime \prime}$ BT. Akusisi data dilakukan di sekitar sumur X.

\section{Teknik Pengolahan Data}

Data hasil akusisi yang didapat dari lapangan memiliki tipe ekstensi .SEGY dan diolah menggunakan software Reflexw versi 5 produksi Sandmeier (2008). Pada penelitian ini dilakukan dua cara tahapan pengolahan data yang kemudian akan dibandingkan hasilnya. Cara pengolahan data yang hasilnya paling baik akan digunakan untuk pengolahan data berikutnya dan hasilnya akan digunakan untuk interpretasi.

Dua cara tahapan pengolahan data dalam penelitian ini adalah cara 1 (Gambar 4), yaitu dengan melakukan proses dekonvolusi setelah bandpass frekuensi dan cara 2 (Gambar 5) dengan melakukan proses dekonvolusi setelah $\mathrm{f}-\mathrm{k}$ filter. Hasil dari pengolahan data cara 1 dan cara 2 dibandingkan untuk mengetahui hasil yang paling baik (Gambar 8 dan Gambar 9).

\section{Teknik Interpretasi}

Hasil pengolahan data GPR disebut dengan radargram. Radargram menampilkan kumpulan nilai amplitudo gelombang yang ditampilkan sebagai fungsi posisi (sumbu horizontal) dan waktu (sumbu vertikal). Waktu tersebut adalah waktu tempuh dua arah gelombang.

Teknik interpretasi pada hasil data GPR penelitian ini sangat dibantu dengan adanya data bor sebagai data ikat. Dengan adanya data bor, interpretasi terhadap sebaran fasies karbonat yang ada di bawah permukaan dapat dilakukan dengan lebih tepat. 


\section{MAKALAH ILMIAH}

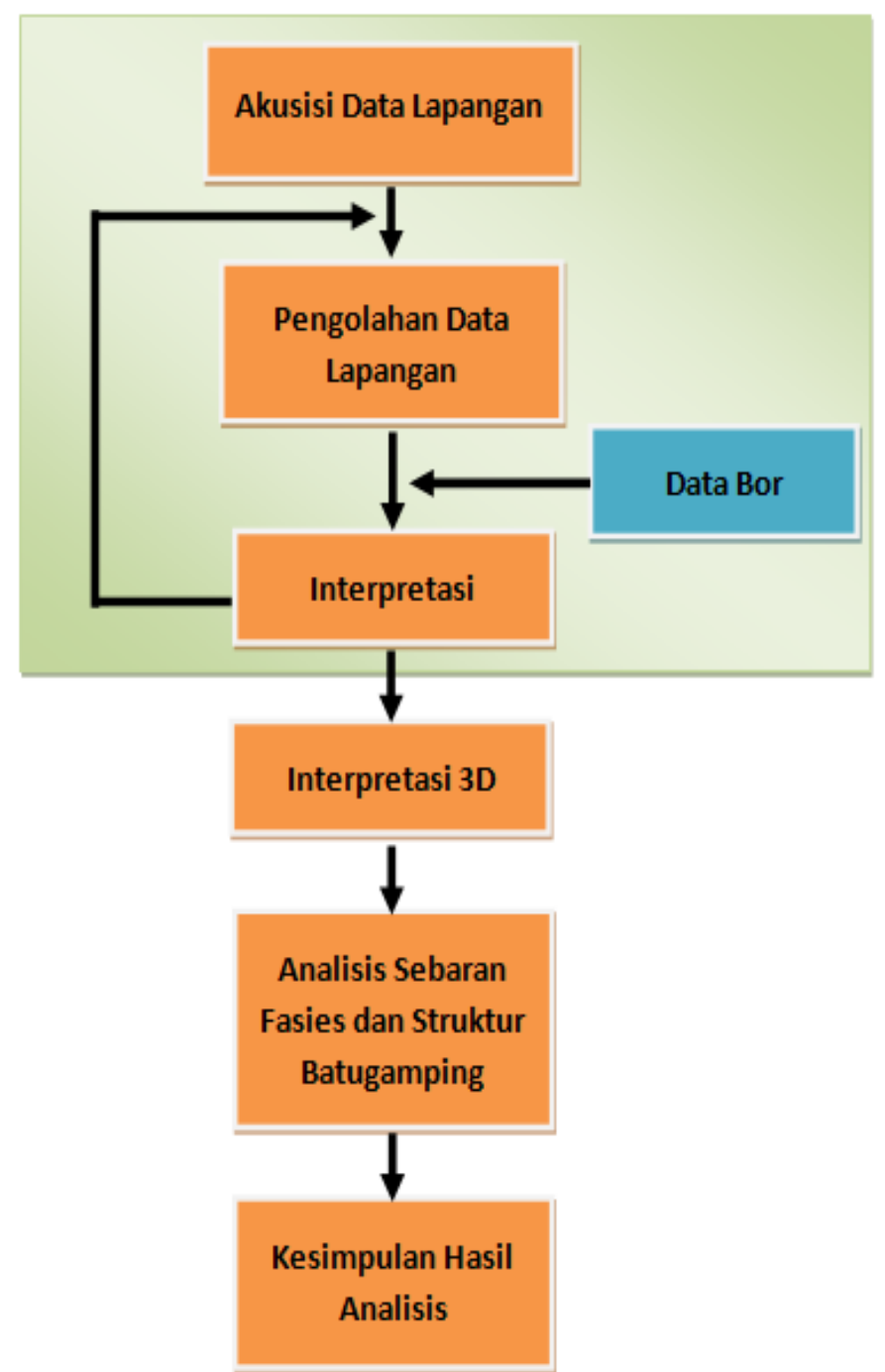

Gambar 3. Diagram alur penelitian

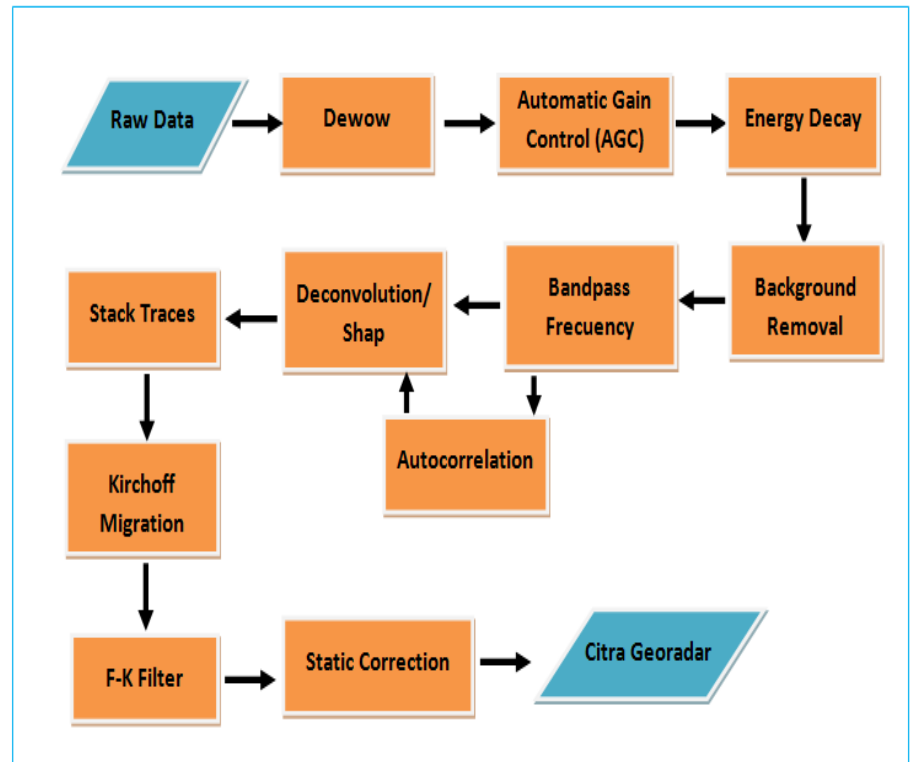

Gambar 4. Tahapan pengolahan data GPR (metode 1) 


\section{MAKALAH ILMIAH}

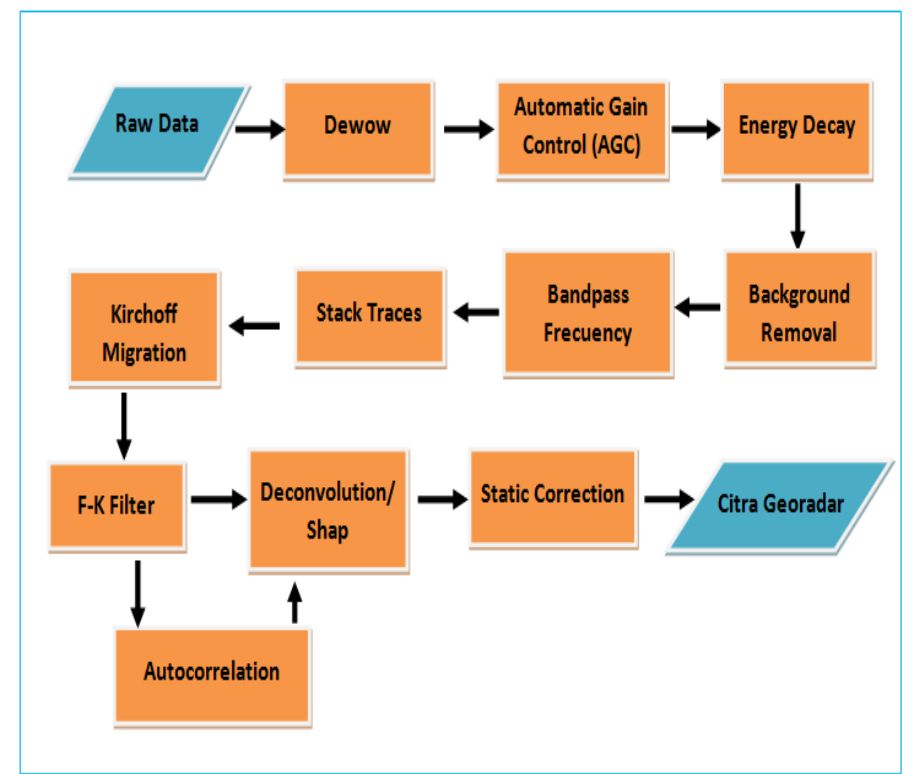

Gambar 5. Tahapan pengolahan data GPR (metode 2)

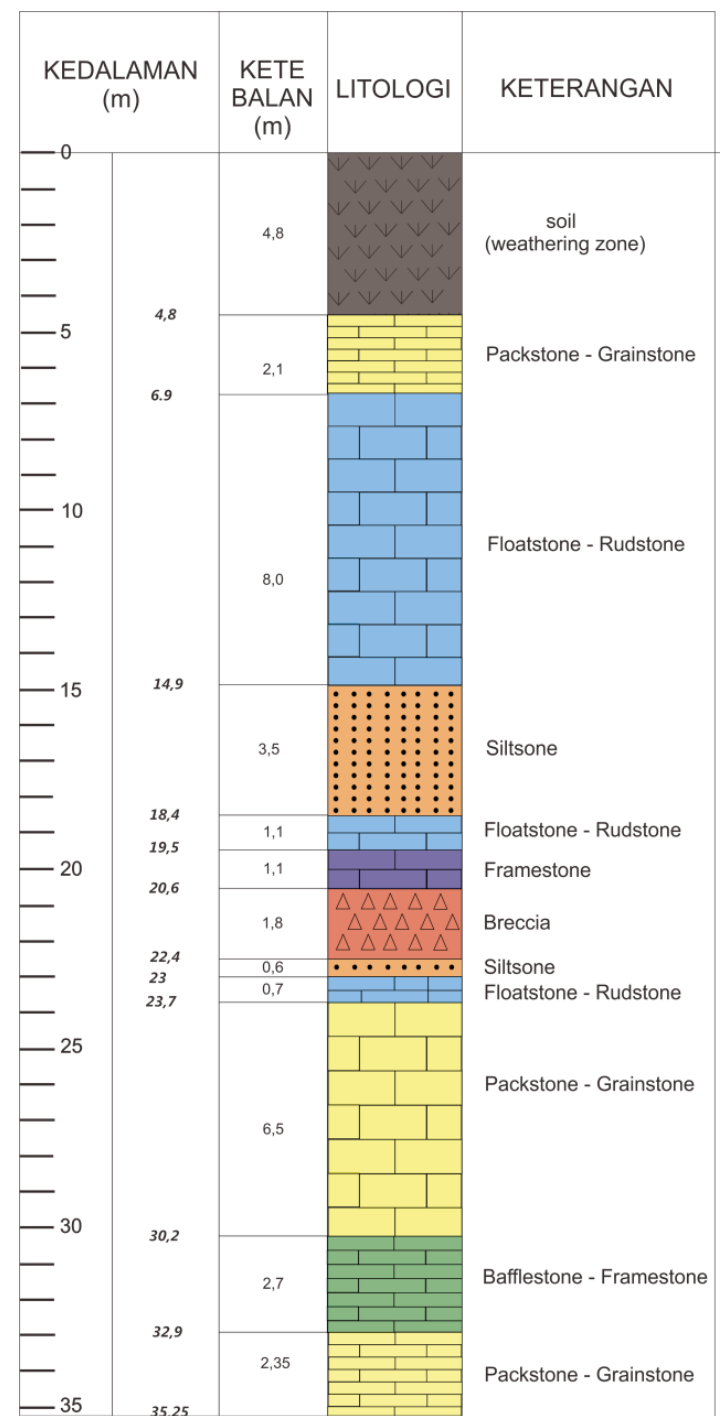

Gambar 6. Litologi sumur pemboran X 
Data bor dan data GPR saling menunjang, data bor dapat menentukan kedalaman suatu fasies (Gambar 6) dan memberikan informasi bawah permukaan secara vertikal, sedangkan data GPR dapat membantu sebaran dan memberikan informasi bawah permukaan lateralnya. Selain itu, interpretasi dilakukan dengan memperhatikan adanya keseragaman amplitudo, kecepatan rambat gelombang, kontinuitas, bentuk gelombang, pola difraksi, dan warna pada radargram (Baker and Harry, 2007). Dari parameter ini, dapat ditentukan batas litologi, perkiraan jenis litologi, kondisi struktur, dan berbagai macam bentuk material bawah permukaan.

\section{HASIL DAN PEMBAHASAN}

Desain survey berbentuk persegi panjang dengan dua line yaitu Line 2 dan Line 3 melewati sumur, sedangkan Line 1 sejajar dengan Line 3 dan Line 4 sejajar dengan Line 2 (Gambar 7).

Hasil dari pengolahan data pada Line 4 dengan menggunakan cara 1 yaitu dengan melakukan proses dekonvolusi setelah bandpass frekuensi ditunjukkan dengan Gambar 8, sedangkan hasil pengolahan data dengan cara 2 dengan melakukan proses dekonvolusi setelah $\mathrm{f}-\mathrm{k}$ filter ditunjukkan dengan Gambar 9.

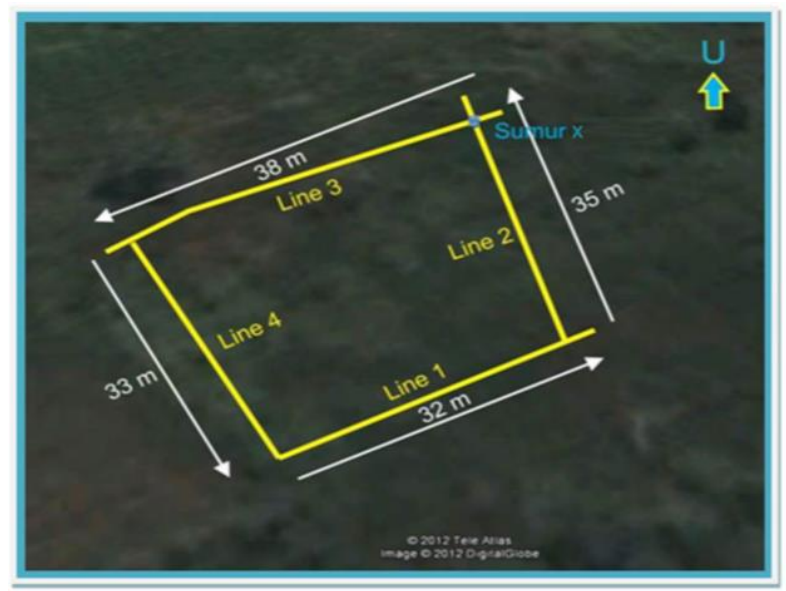

Gambar 7. Lintasan surver GPR

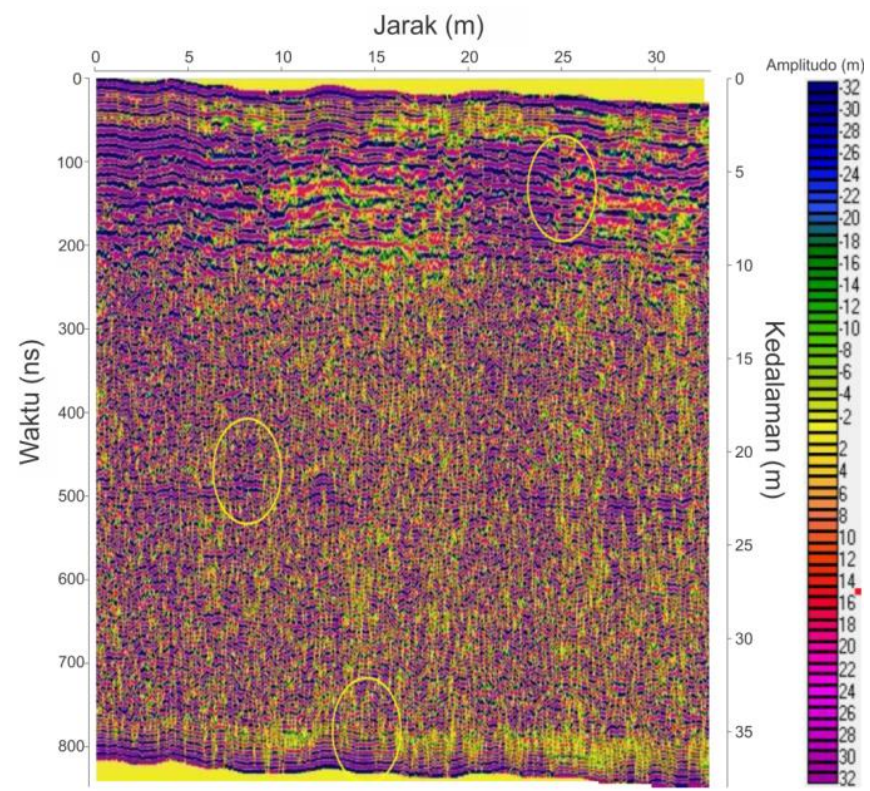

Gambar 8. Hasil pengolah data dengan metode 1 pada Line 4 


\section{MAKALAH ILMIAH}

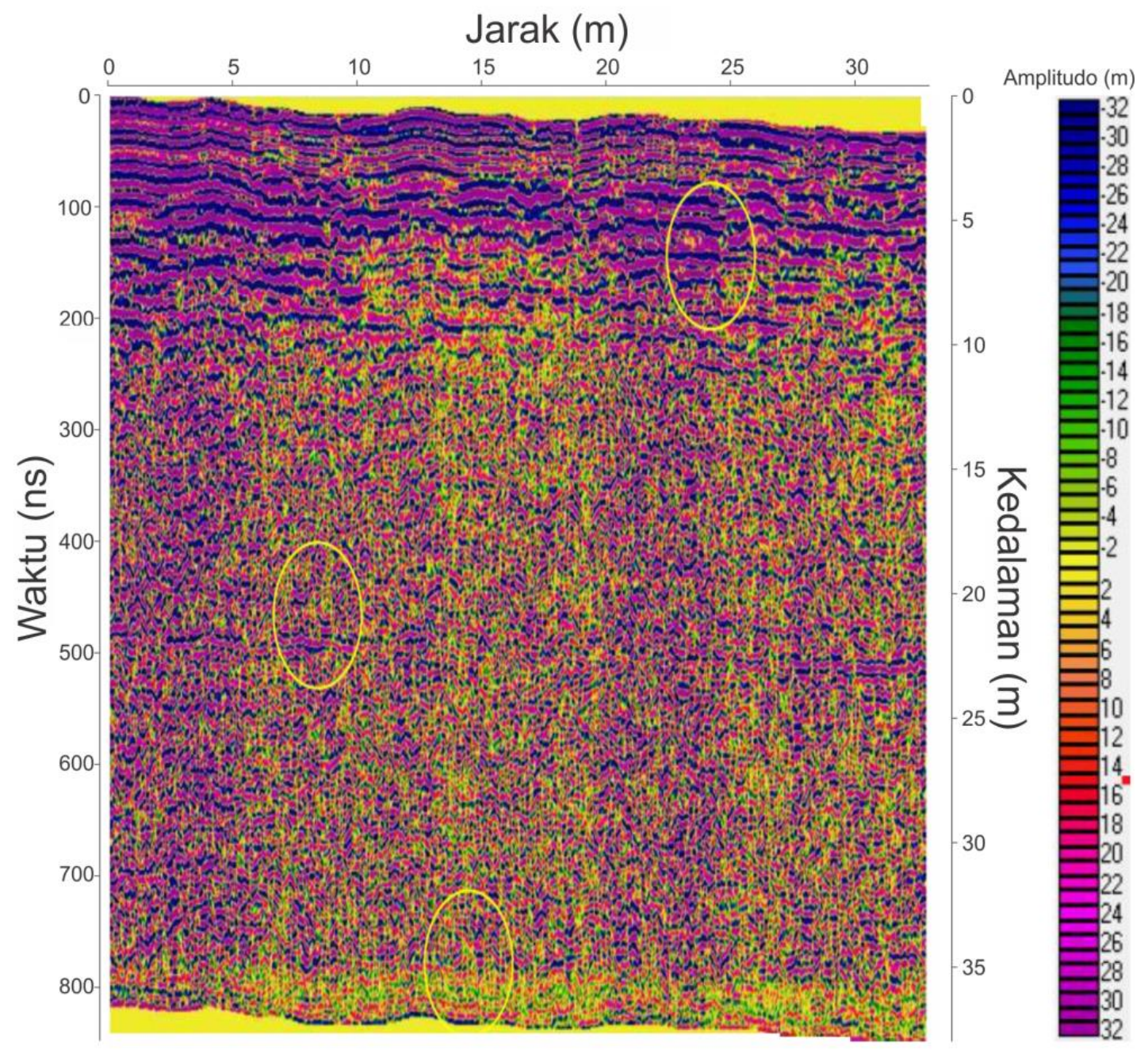

Gambar 9. Hasil pengolah data dengan metode 2 pada Line 4

Perbedaan dalam proses pengolahan data dapat menghasilkan hasil citra georadar yang berbeda. Pada penelitian ini, proses dekonvolusi dilakukan pada tahapan yang berbeda pada masing-masing metode. Pada cara yang pertama proses dekonvolusi dilakukan setelah proses bandpass frekuensi, sedangkan pada cara yang kedua dekonvolusi dilakukan setelah proses $\mathrm{f}-\mathrm{k}$ filter. Dua cara pengolahan data tersebut memberikan hasil yang berbeda, dimana hasil pengolahan cara yang pertama memperlihatkan kemenerusan reflektor yang lebih terlihat sampai kedalaman $36 \mathrm{~m}$ dibandingkan hasil pengolahan data yang kedua hanya baik memperlihatkan kemenerusan reflektor sampai kedalaman sekitar $10 \mathrm{~m}$. Dengan demikian, pengolahan data dengan cara yang pertama yang digunakan untuk pengolahan data selanjutnya.
Pada data hasil pengolahan di atas kemudian dilakukan well-tie radargram dengan data bor (Geological Research Group ITB, 2009) untuk mengetahui sebaran litofasies secara vertikal. Agar pengolahan data menghasilkan kedalaman yang sesuai dengan data bor, maka nilai kecepatan radar yang digunakan dalam pengolahan data harus sesuai dalam penelitian ini. Kecepatan yang digunakan adalah $90 \mathrm{~m} / \mu \mathrm{s}$. Perpaduan antara data bor dan hasil pengolahan data GPR akan menghasilkan data yang lebih akurat. Hasil interpretasi dari pengolahan data yang diikat dengan data bor terdiri dari Line 1 (Gambar 10), Line 2 (Gambar 11), Line 3 (Gambar 12), Line 4 (Gambar 13), dan perpotongan Line 1, Line 2, Line 3, dan Line 4 (Gambar 14). 


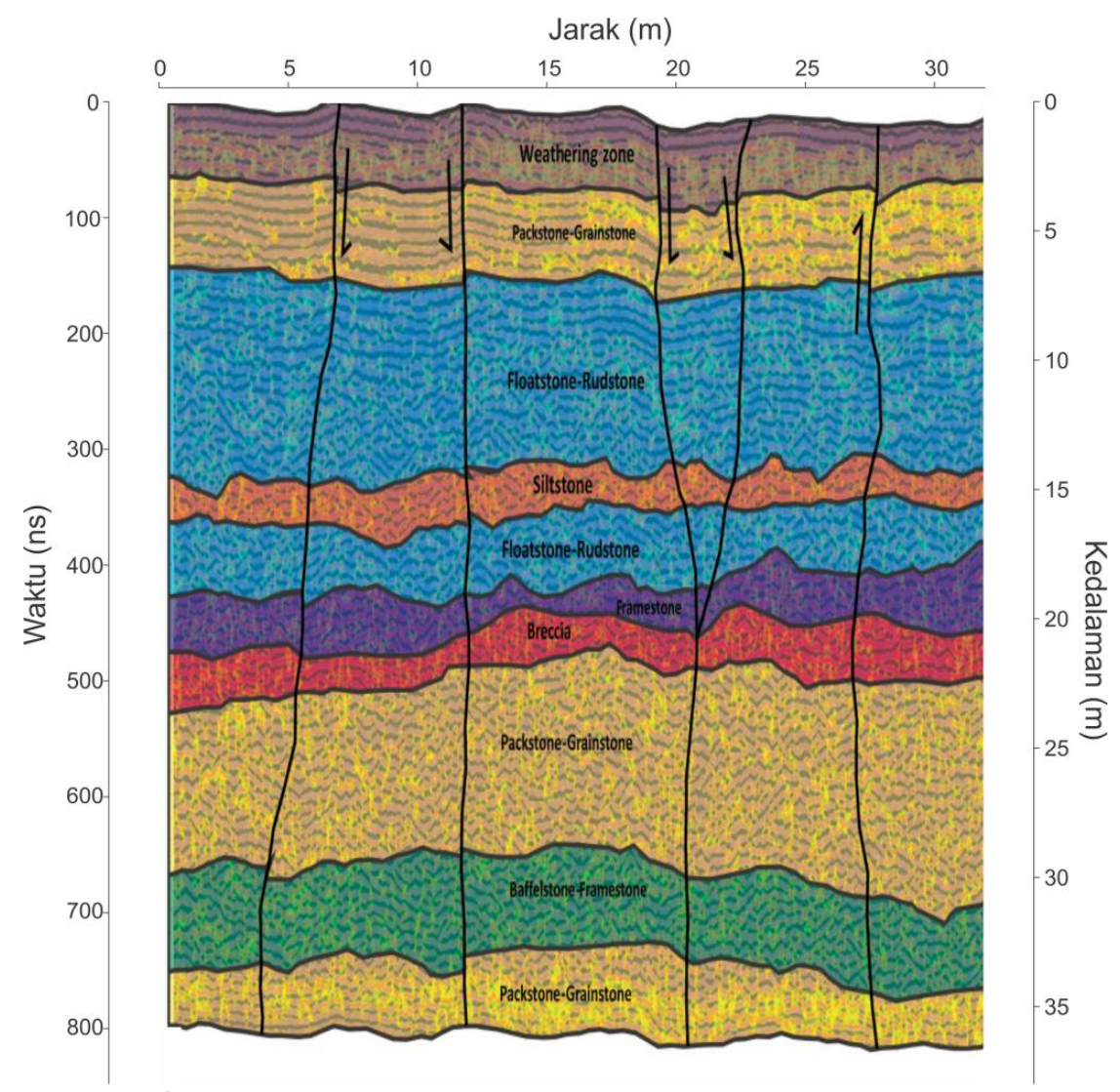

Gambar 10. Hasil interpretasi data lintasan Line 1

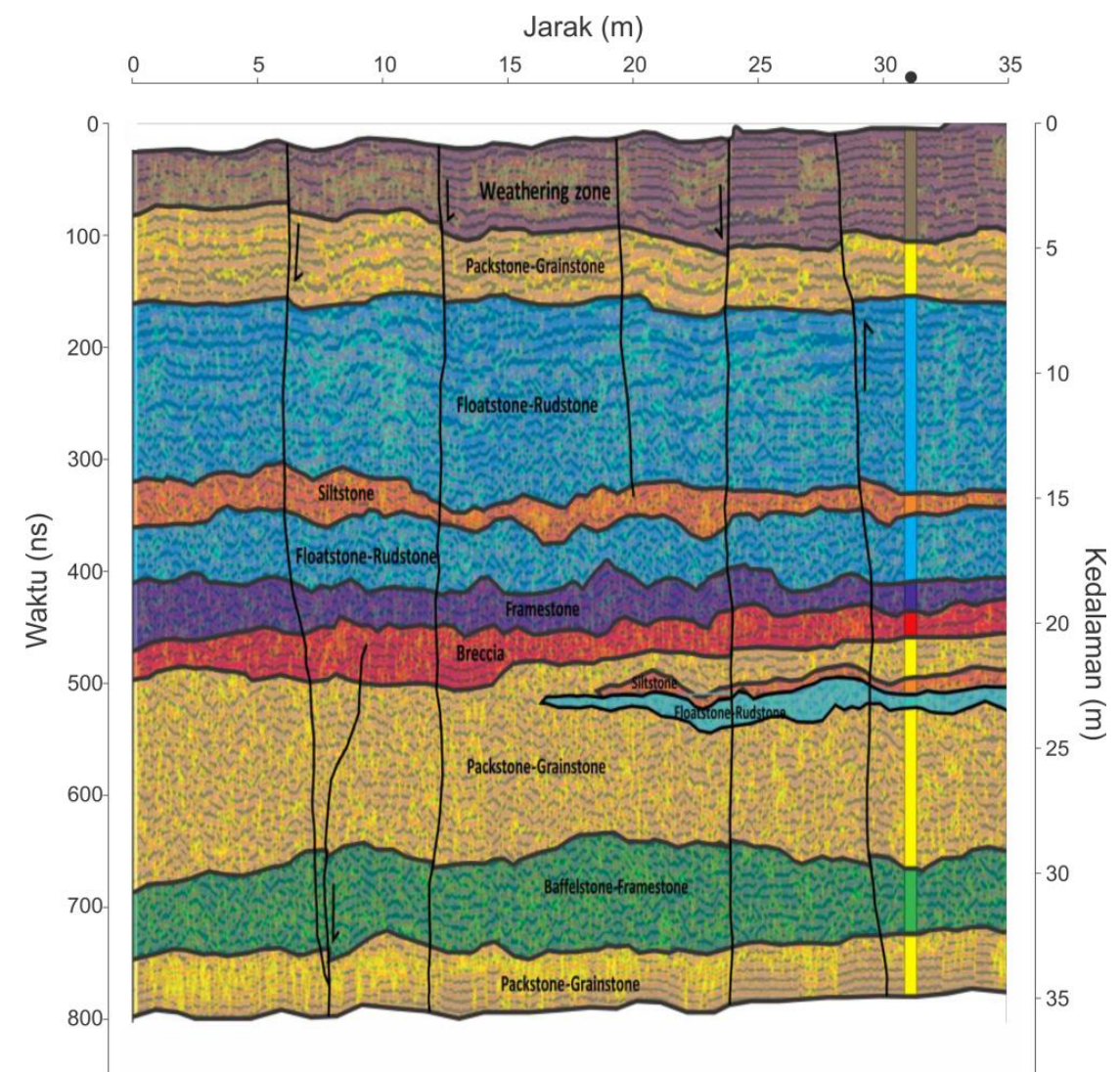

Gambar 11. Hasil interpretasi data lintasan Line 2 


\section{MAKALAH ILMIAH}

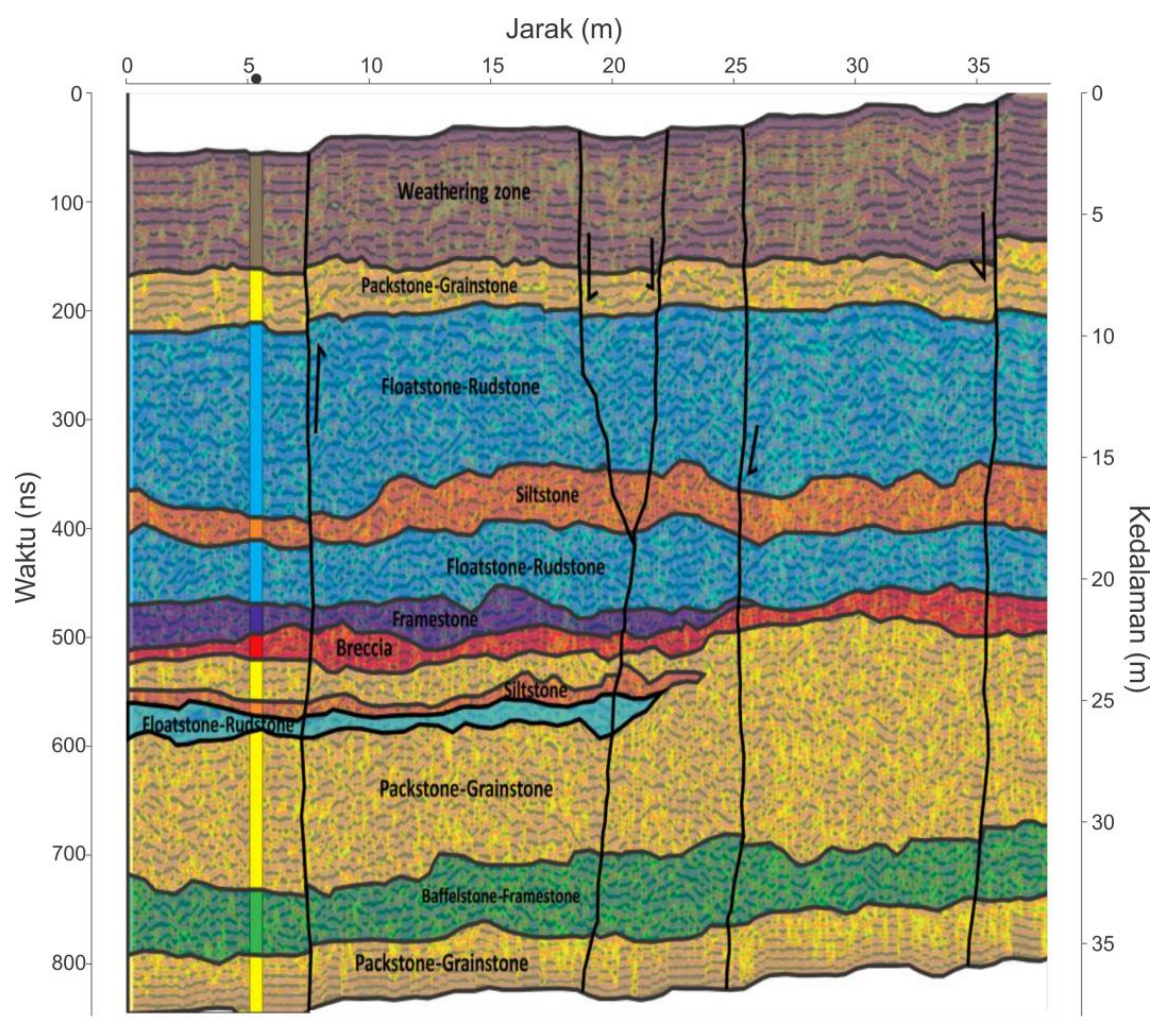

Gambar 12. Hasil interpretasi data lintasan Line 3

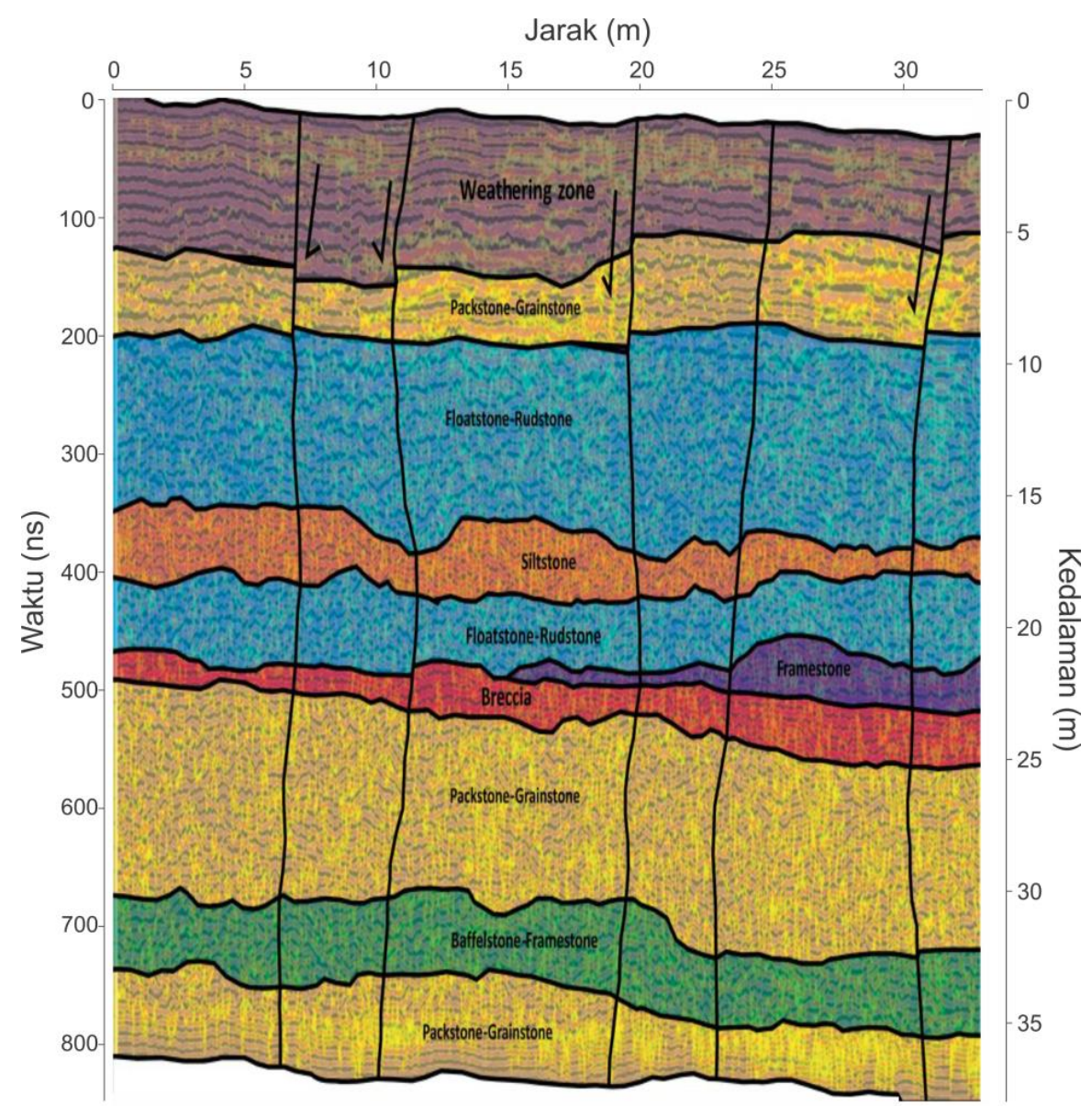

Gambar 13. Hasil interpretasi data lintasan Line 4 


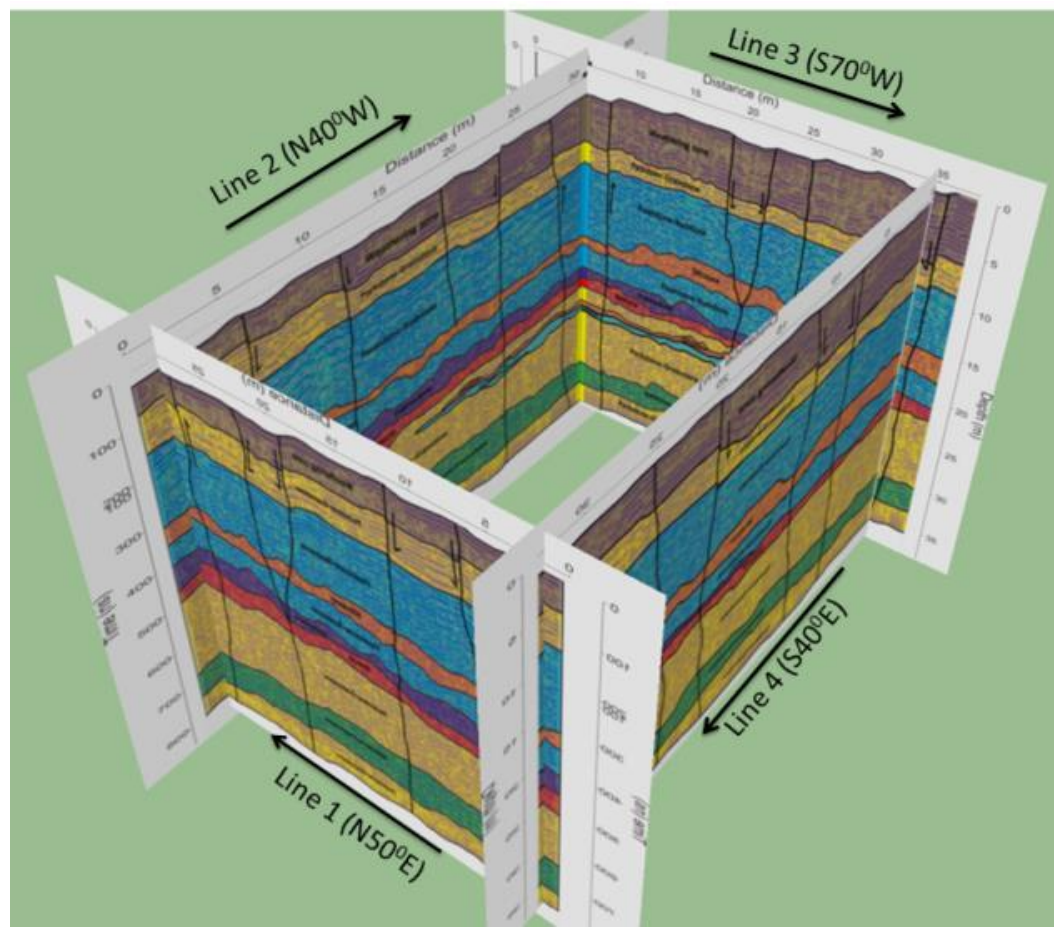

Gambar 14. Interpretasi hasil perpotongan Line 1, Line 2, Line 3, dan Line 4

Fasies karbonat merupakan suatu tubuh batuan karbonat yang memiliki kombinasi ciri atau karakteristik yang khas dari batuan karbonat yang ada di atas, bawah maupun di sekelilingnya. Klasifikasi yang digunakan dalam tulisan ini adalah klasifikasi Dunham (1962) dan klasifikasi Embry-Klovan (1971). Fasies batu gamping karbonat di Cikamuning sumur $X$ dari tua ke muda adalah packstonegrainstone, baffelstone-framestone, packstone-grainstone, floatstone-rudstone, packstone-grainstone, breccia, framestone, silstone, floatstone-rudstone, packstone-grainstone dengan dominasi fasies adalah packstone-grainstone dan floatstone-rudstone (Geological Research Group ITB, 2009).

Pada Line 2 dan Line 3 di kedalaman 23 $\mathrm{m}$ s.d. $25 \mathrm{~m}$ terdapat sisipan silstone dan floatstone-rudstone dengan ketebalan kurang dari $1 \mathrm{~m}$ yang semakin menipis dan menghilang ke arah tenggara. Pada Line 3 dan Line 4 fasies framestone semakin menipis dan menghilang ke arah baratdaya. Pada citra georadar terlihat perubahan fasies batugamping Formasi Rajamandala, yang dicirikan oleh adanya hubungan lateral membaji dengan struktur geologi yang terdapat adanya rekahan, sesar normal dan sesar naik dengan dominasi sesar normal yang terlihat jelas di kedalaman dangkal, sedangkan pada kedalaman yang lebih dalam kurang terlihat adanya sesar.

\section{KESIMPULAN}

Setelah dilakukan penelitian pada batugamping Formasi Rajamandala sekitar sumur $X$ daerah Cikamuning maka didapatkan bahwa metode georadar dengan frekuensi $75 \mathrm{MHz}$ cukup baik untuk mendeteksi struktur dan sebaran fasies arah lateral batugamping karena memiliki resolusi vertikal yang mampu mendeteksi lapisan dengan ketebalan minimum $0,3 \mathrm{~m}$. Struktur geologi daerah sekitar sumur $X$ Cikamuning didominasi sesar turun dan batas fasies dicirikan dengan adanya pembajian. Daerah sekitar sumur X Cikamuning adalah slope dari terumbu karena didominasi fasies packstone-grainstone dan floatstonerudstone dengan arah pengendapan ke arah baratdaya. 


\section{MAKALAH ILMIAH}

\section{UCAPAN TERIMA KASIH}

Penulis mengucapkan terima kasih yang sebesar-besarnya kepada seluruh pihak yang membantu dalam pengerjaan tulisan mulai dari tahap awal pengerjaan sampai ke tahap publikasi.

\section{DAFTAR PUSTAKA}

Annan dan Davis, 1989. Ground Penetrating Radar, Workshop Notes, Sensor \& Software Inc.

Baker, G.S., dan Harry, 2007. Stratigraphic analysis using GPR. Geological Society of America.

Baker, P.L., 1991. Response of ground penetrating radar to bounding surfaces and lithofacies variations in sand barrier sequence. Expl Geophys ,22,: h. 19-22.

Dunham, R.J., 1962. Classification of carbonate rocks according to depositional textures. AAPG Memoir No. 1.
Embry, A.F., dan Klovan, J.E., 1971. Late Devonian reef tract on Northeastern BanksIsland. Canadian Petroleum Geology Bulletin, 19, h. 730-781.

Geological Research Group, 2009. Geology of Rajamandala Complex. Faculty of Earth Sciences and Technology ITB.

Nugroho, D., dkk., 2009. Significance of the sedimentology and stratigrafy for the evolution and demise of the oligocene rajamandala limestone, Padalarang, West Java, Indonesia. Indonesian Petroleum Association.

Sandmeier, K.J., $1998 . \quad$ ReflexW Version 5 Reference Manual. Http://www.sandmeier-eo.de/Reflex/ reflexw.html.

Siregar, S., 2005. Sedimentasi dan model terumbu Formasi Rajamandala di daerah Padalarang-Jawa Barat. Riset Geologi dan Pertambangan, Jilid 16 No.1.

Sudjatmiko, 1972. Peta Geologi Lembar Cianjur, Jawa. Pusat Penelitian dan Pengembangan Geologi, Bandung.

\begin{tabular}{ll|}
\hline Diterima & $:$ 1 September 2016 \\
Direvisi & $: 15$ Oktober 2016 \\
Disetujui & $: 17$ November 2016
\end{tabular}

